wpisane tzw. site-specific art, uruchamiają tkwiący w nim rezonans innych miejsc, są projekcją pragnień, a jednocześnie gorzkim zaprzeczeniem tego, czym owo miejsce rzeczywiście jest. Do tego rezonansu należą wyobrażenia miejsc Innych jako „cudownych”, rajskich. One same są jednak rezonansem tego, czego w graffiti Banksy'ego nie odnajdziemy i czego dotkliwy brak jego prace uwydatniają: miejsca normalnego. Utopii.

\title{
Kamera i poeta doctus? O filmach Edwarda Żebrowskiego z perspektywy lotu ptaka
}

\section{ANDRZEJ SZPULAK}

Jeśli rozważa się kwestię białych plam w dorobku polskiego piśmiennictwa filmowego poświęconego historii rodzimej kinematografii, to twórczość Edwarda Żebrowskiego staje się obiektem szczególnie ważnym i ciekawym. Nie napisano o niej prawie nic, a przecież, gdyby zapytać jakąkolwiek kompetentną osobę, musiałaby odpowiedzieć, że było warto i było o czym. Fakt, że reżyser zrealizował samodzielnie zaledwie pięć filmów (dwa filmy krótkie oraz trzy pełnometrażowe filmy fabularne) [1], po czym z powodu choroby zamilkł, nie powinien być powodem do ustawiania go w drugim czy może trzecim szeregu polskich reżyserów, a tym bardziej nie powinien być powodem odsyłania go w niebyt. Ta ostatnia praktyka, trzeba przyznać dominująca w recepcji dzieł Żebrowskiego, jest tym boleśniejsza, że owo odesłanie w niebyt odbywa się właśnie bez komentarza. Garstka krótkich i rozproszonych tekstów krytycznych, czy wywiadów towarzyszących premierom kolej-

[1] Wraz z K. Zanussim E. Żebrowski współreżyserował jeszcze dwa filmy w Zachodnich Niemczech. Były to Die Nachtdienst (1975) oraz Die Unerreichbare (1982).

[2] B. Zmudziński, Edward Żebrowski - kino dyskursu moralnego, w: Autorzy kina polskiego, red. G. Stachówna i J. Wojnicka, Kraków 2004, ss. 79-90.

[3] K. Mąka-Malatyńska, A Attempt To Read Lem's And Żebrowski's "The Hospital of The Transfiguration” In A New Way, „Images” vol. VI, nr 11-12, 2008, ss. 57-66. nych utworów z natury rzeczy nie może być traktowana jako dostateczne wyjaśnienie fenomenu tego kina. A poza nimi jest już niewiele. Syntetyczny artykuł Bogusława Zmudzińskiego, opublikowany w tomie poświęconym mniej eksponowanym, a istotnym twórcom polskiego filmu[2], czy też odnoszący się do zagadnienia bardziej szczegółowego i jednego tylko dzieła tekst Katarzyny Mąki-Malatyńskiej [3], choć budzą uznanie, tylko cząstkowo oddają rangę i wagę przedmiotu. Zresztą, co symptomatyczne, pierwsza ze wspomnianych publikacji w tego rodzaju projekcie, jakim sa Autorzy kina polskiego, po prostu musiała się znaleźć, zaś druga zrodziła się z zainteresowania autorki problemem obrazów Zagłady w kinie polskim, dla którego Szpital Przemienienia (1978) stał się ważną egzemplifikacją.

W świadomości profesjonalnych filmoznawców autor Dnia listopadowego (1970) funkcjonuje oczywiście jako twórca dość wybitny, ale nie wzbudzający emocji, a nawet nieco anachroniczny. W świadomości zagorzałych miłośników polskiego kina funkcjonuje przede wszystkim jako artystyczny partner Krzysztofa Zanussiego z początków jego kariery, błyszcząc światłem odbitym. Znana jest też czasem jego działalność scenopisarska, czy pedagogiczna. Natomiast w świadomości tylko nieco mniej zagorzałych miłośników kina nie funkcjonuje on niestety w żadnym stopniu, nawet na poziomie rozpoznawalności nazwiska. Zapewne jedynie w środowisku 
filmowców - i to nie wyłącznie polskich[4] - cieszy się on należnym mu autorytetem.

Można by stwierdzić, że po ukazaniu się z uwagi na jej rozmiary siłą rzeczy dość pobieżnej wypowiedzi Zmudzińskiego pożądana jest nie tyle kolejna, podobnie minimalistyczna synteza twórczości Edwarda Żebrowskiego, co opracowanie bardziej szczegółowe, najlepiej monografia książkowa, która spowodowałaby głębszą jej interpretację i stałaby się narzędziem jej popularyzacji - oczywiście rozumianej względnie. To prawda. Skoro jednak takiej książki nie widać na horyzoncie, warto wykonać jeszcze jeden rzut oka z perspektywy lotu ptaka. Warto, gdyż tekst Zmudzińskiego oprócz ewidentnych zalet ma również słabości. Pierwszą jest nadmierne skupienie się na twórczości wspólnej Żebrowskiego i Zanussiego, której autor poświęca połowę tekstu. Prowadzi to w konsekwencji do faktu, iż nie zarysowany zostaje wyraźnie oryginalny idiom dzieła tego pierwszego. Dwóm jego kluczowym filmom, Szpitalowi Przemienienia oraz W biały dzień (1981), poświęcona została tylko jedna trzecia tekstu. I tutaj powstaje kolejny problem. Otóż badacz zdaje się umykać przed bardziej szczegółową interpretacją filmów ku analizom porównawczym. Wiele miejsca poświęca Spirali Krzysztofa Zanussiego (1978) oraz Goraczce Agnieszki Holland (1981). Porównania są trafione, ale samą swą obecnością w tak krótkim tekście utrudniają pogłębienie zarysowanych wątków. Po lekturze tekstu Zmudzińskiego można odnieść delikatne wrażenie, iż mimo całej wyrażanej explicite atencji autora dla reżysera powstał on na zamówienie, niejako z obowiązku, w mniejszym natomiast stopniu w konsekwencji własnych zainteresowań czy fascynacji.

Tymczasem Żebrowski potrafi być fascynujący, i to sam w sobie - zarówno jako twórca, jak i komentator własnych dokonań, czy własnej wizji sztuki filmowej. Żeby się o tym przekonać, wystarczy przywołać pewną jego wypowiedź: „Sztuka ma u nas szanse, by nie być biznesem. Opłacalność i kasa nie musi być w naszym ustroju kryterium podstawowym.
Zamiast wmawiać w siebie, iż dla pozyskania widzów musimy robić połowę filmów obliczonych na prymitywne gusty, a dopiero resztę mogą stanowić filmy wartościowe. Róbmy same filmy dobre i postarajmy się, żeby dotarły do widza”. Nieco dalej konkluduje: „Zjawiskiem peryferyjnym powinno stać się kino rozrywkowe" [5]. W reakcji na te słowa wypada zawołać: Jaki piękny anachronizm! Cóż za jednostronność! I wołanie to okrasić śmiechem - takim wesołym, spontanicznym, tak oczywistym, że pozbawionym nawet ironii, a opatrzonym jedynie nutką wyższości, jaką musi mieć Polak po dwudziestu latach życia w nowym systemie społeczno-ekonomicznym wobec swego antenata tkwiącego w samym środku peerelowskiego absurdu, a także jaką musi mieć człowiek obecnej doby, tak bardzo związany z mechanizmami kultury popularnej dla wyznawcy artystycznego elitaryzmu i marzyciela.

Oczywiście sankcja polityczno-ideologiczna nie pojawia się w przywołanej wypowiedzi dlatego, żeby kompan i współwięzień Ireneusza Iredyńskiego miał być cynicznym czy naiwnym piewcą panującego ustroju. Argumentu „ustroju” używało się wówczas najzupełniej instrumentalnie, kiedy było to poręczne dla uzasadnienia jakiegoś działania, nawet zupełnie przeciwnego obowiązującemu porządkowi ideologicznemu. Zresztą dziś praktykuje się zupełnie tę samą taktykę. Z drobna tylko zmianą - zamiast ustroju pojawia się demokracja.

Tak czy owak anachronizm i elitaryzm to z naszej perspektywy, jak się zdaje, podstawowe określenia postawy twórczej autora Ocalenia (1972). A jak to właściwie $\mathrm{z}$ nimi jest? $\mathrm{O}$ anachronizmie wspomniał już Zmudziński, kiedy pisał: „Cechę, którą najłatwiej byłoby przypisać twórczości artysty, można by nazwać «bolesną anachronicznością». Towarzy-

[4] Wykładał on przecież w wielu szkołach filmowych Zachodniej Europy.

[5] S. Latałło, G. Królikiewicz, K. Mętrak, B. Michałek, T. Zygadło, E. Żebrowski, Nowe miejsce filmu (dyskusja), „Film” 1971, nr 45. 
szy ona również kategorii tragiczności, zupełnie nieadekwatnej do współczesnej epoki zdominowanej przez wybory konsumpcyjne, a nie egzystencjalne" [6]. W pewnym sensie wypadałoby się z tym zgodzić[7], ale również nieco rozwinąć i poszerzyć uzasadnienie owej anachroniczności.

W swoich nakręconych mniej więcej w ciągu dekady filmach Żebrowski okazał się dzieckiem i zarazem współtwórcą epoki, w której triumfy święciło kina autorskie, rozumiane jako osobisty przekaz artysty, pozbawiony wymuszonych koncesji na rzecz kina popularnego - czasem co prawda wykorzystujący jego konwencje, ale zwykle obojętny na nie lub wręcz je kontestujący. Reżyser zgodnie z deklaracją odżegnywał się od jakiejkolwiek formy kontaktu z nim[8]. Rozwijał swój język, oparty na antydramatyczności, na narracji eliptycznej i epizodycznej, burzącej związek przyczyny ze skutkiem, język osłabiający bezpośrednie oddziaływanie emocji, likwidujący prymat słowa, zastępowanego przez mikroanalizę drobnych zachowań, mimiki i spojrzeń (szczególnie w Ocaleniu), język uruchamiający wieloznaczny i pogłębiony dyskurs intelektualny, sprzyjający ukazaniu człowieka podlegającego wewnętrznej przemianie, procesowi dojrzewania. Jest to niewątpliwie język

[6] B. Zmudziński, op.cit., s. 80.

[7] Nie odnoszę się tutaj do wywołanej kategorii tragiczności, która z pewnością w swoisty sposób jest obecna we wszystkich filmach Żebrowskiego, lecz jej analiza wymaga osobnego opracowania.

[8] Reżyser uznawał się za zainspirowanego osiągnięciami francuskiej Nowej Fali. Inspiracja ta wiązała się jednak $\mathrm{z}$ dowartościowaniem indywidualnego autorstwa, $\mathrm{z}$ nowatorskim i bardzo swobodnym podejściem do kwestii narracji, z wyzbywaniem się wszelkich konwencji teatralnych, np. $\mathrm{w}$ dziedzinie scenografii lub aktorstwa, natomiast $\mathrm{w}$ żadnym wypadku nie $\mathrm{z}$ zainteresowaniem kinem popularnym, które Francuzi, a szczególnie Truffaut czy Godard, niewątpliwie przejawiali.

[9] W większym stopniu dotyczy to kina zagranicznego niż polskiego, gdyż rodzime z rzadka tylko dotyka problemów etycznych, a jeszcze rzadziej robi to bez naiwności. kina zapominanego i traktowanego nawet z pewną niechęcią - typowy „bergaman”.

Może bardziej jeszcze od samej formuły tego kina anachroniczny wydaje się przejawiający się w nim świat wartości. Pozostając na poziomie nader ogólnym, trzeba stwierdzić, że Żebrowski jawi się jako reżyser-myślicielmoralista. Zaś fundamentem etycznym jego rozważań jest dekalog. a w szczególności treść przykazania piątego. Zaś oprócz dekalogu także związany z jego duchową rzeczywistością nakaz miłości bliźniego. Rzeczywistość ta ma rzecz jasna swój wymiar religijny, który jest arcyważny, ale do niego wypadnie odnieść się nieco dalej. Tymczasem interesuje nas ona jako imperatyw czysto etyczny. W związku $\mathrm{z}$ nią stawiane jest też pytanie o sens cierpienia, oblicze zła oraz możliwość ocalenia. Obecnie natomiast, jeśli kino podejmuje zagadnienia etyczne, to nade wszystko w kontekście zagadnienia tolerancji, akceptacji mniejszości, czy indywidualności, w kontekście seksualności i płciowości człowieka, w poczuciu całkowitej absurdalności jakiegokolwiek cierpienia, często abstrahując od zapisów z kamiennych tablic[9]. Przypomina się tu pewna, bardzo krótka scena z Ćwiczeń warsztatowych Marcela Łozińskiego (1984), w której na pytanie o obowiązujące go zasady jeden z młodych ludzi po chwili namysłu, jakby gorączkowo szukając w głowie dobrej odpowiedzi, mówi: dekalog. Przypomina się też w swoim czasie niezwykle popularny cykl filmów telewizyjnych Krzysztofa Kieślowskiego. W ciągu dwudziestu kilku lat ta tak, zdawałoby się, trwała podstawa etyczna ludzkiego widzenia świata, została w przekazie filmowym zachwiana, a może nawet odsunięta.

Ważne jest przy tym jeszcze, jak wygląda zaangażowanie etyczne kina dziś, a jak wyglądało u Żebrowskiego i jego filmowych krewniaków. Autor Szpitala Przemienia w gęstej atmosferze znaczeń nade wszystko stawia pytania. Dominuje sfera niepewności, wątpliwości, niepokoju, nieustannej weryfikacji wartości. Współcześnie natomiast mamy do czynienia z mniej lub bardziej udatnie „promowany- 
mi” tezami i postulatami: z plakatowością, jak choćby w Pręgach Magdaleny Piekorz (2004), z baśniowymi historyjkami wyposażonymi w zbanalizowany morał w rodzaju Komornika Feliksa Falka (2005), bądź z pozornie drastycznymi manifestacjami nihilizmu, to np. w 33 scenach $z \dot{z} y$ cia Małgorzaty Szumowskiej (2008). Filmy, także te lepsze - Krzysztofa Krauzego, czy Jana Jakuba Kolskiego, odarte są z dynamiki wewnętrznego dialogu. Nawet mimowolnie trochę musieliśmy się do tego przyzwyczaić. I również stąd bierze się owo wrażenie nieprzystawalności utworów Żebrowskiego do współczesności, do nas samych.

Gdy spojrzy się na film $W$ biały dzień na myśl przychodzi jeszcze jedna forma anachronizmu. Oto pojawia się utwór - co prawda bardzo swobodnie, jeśli chodzi o faktografię, ale też bardzo wyraziście - zanurzony w historię, w poważnych intencjach operujący jej obrazem, a jeszcze do tego film $\mathrm{z}$ kluczem. Niemałego trudu wymaga rozszyfrowanie konkretnych postaci historycznych, kryjących się wśród ekranowych protagonistów. Stanisław Brzozowski, Józef Piłsudski, Władysław Podkowiński - to tylko te najbardziej czytelne. Trud w istocie nie jest jednak niezbędny, wszak utwór ten to - żeby posłużyć się udatną formułą Tadeusza Sobolewskiego - historyczna fantazja[10]. Niezbędna natomiast pozostaje głęboka świadomość konkretnego momentu historycznego, jego specyfiki, przyczyn, dla których uzyskał takie, a nie inne oblicze i konsekwencji, które przyniósł w przyszłości, a więc po prostu znajomość historii. A przy obecnie obowiązującej i skrzętnie rozwijanej formule edukacyjnej staje się to przywilejem bardzo niewielu. We współczesnym kinie historia na ogół jest tylko kostiumem, elementem widowiska, kreowanym z dbałością o efekt wizualny, nie zaś o ścisłość, czy wewnętrzną prawdę odmiennego, bo minionego czasu. Wedle obiegowych opinii taki często nieco plastikowy obraz dziejów miałby sprzyjać uniwersalizmowi przesłania. Tymczasem rzeczywisty uniwersalizm, taki jak w filmie Żebrowskiego, zwykle nie rodzi się z deficytu historycznego konkretu. Wręcz przeciwnie. Rodzi się on $\mathrm{z}$ odpowiedniego spojrzenia na ów konkret.

Kiedy mówi się o przywileju bardzo niewielu, a takie właśnie słowa padły nieco wyżej, to rzecz jasna unaocznia się wspomniany już problem elitaryzmu. Do niego również odniósł się sam Żebrowski. „Nie wierzę w istnienie ludzi niewrażliwych. - mówił - Przypuszczam, że w najbardziej elitarnym filmie widz obdarzony elementarną wrażliwością znajdzie coś dla siebie. (...) Chyba, że film będzie kompletnym dziwadłem, zrobionym dla pustej zabawy czy szokowania widza" [11]. W dalszej części wywiadu powiada jeszcze, iż odbiorca powinien być traktowany jak twórca, nie zaś jako funkcjonariusz i że ostatecznie chodzi o to, aby wywołać w nim przeżycie estetyczno-moralne, wewnętrzny wstrząs. „Nie robiłem go (chodzi o Ocalenie - przyp. A.S.) z myślą o widzu elitarnym" - konkluduje[12]. I ponownie można byłoby wzruszyć ramionami. Cóż to znów za katartyczna utopia? Sztuka filmowa podążyła wszak w zupełnie inną stronę. Po pierwsze wchłania w siebie schematy kultury popularnej, a po drugie właśnie z szokowania widza czyni jedną z podstawowych wartości. Dawne kategorie, także te antyczne, odeszły w głęboki cień, uległy rozczłonkowaniu. Jeśli więc twórca intencjonalnie nie programował swych utworów jako elitarnych, bo przecież mógł liczyć na nieco inaczej niż współczesna ukształtowaną publiczność, to bez wątpienia taki efekt osiągnął. W mniejszym stopniu w czasie swojej aktywnej działalności reżyserskiej, a obecnie w stopniu niemal doskonałym. Nie wiadomo, czy dzisiaj niczym niewymuszone obcowanie z jego

[10] T. Sobolewski, Polityka i bałagan życia, „Film” 1981, r 11. O fantastyczności świadczy choćby fakt, iż akcję filmu można datować na lata 1908-1909, natomiast na ekranie pojawia się malarz, którego wypada identyfikować z Podkowińskim, zmarłym w 1895 r.

[11] E. Żebrowski, Wszystko zależy od pytań, jakie zadaje film, rozm. B. Janicka, „Kino” 1972, nr 7.

[12] Ibidem, 14. 
utworami nie jest przypadkiem udziałem jednostek.

Zresztą ten elitaryzm, rozumiany jako elitaryzm ducha, wtedy kiedy rodziło się kino Zanussiego i Żebrowskiego był znakiem sprzeciwu wobec oficjalnego porządku wartości, propagowanego sposobu widzenia rzeczywistości, a także wobec reguł życia społecznego. Honor, uczciwość, duma - tak określił Bogusław Zmudziński podstawowe wartości, które konstytuowały - przynajmniej jako punkt dojścia - duchowy świat filmowych bohaterów, wartości wywiedzione przez niego $z$ wnętrza etosu inteligenckiego[13]. Aż się prosi, aby do tego miniinwentarza dorzucić jeszcze co najmniej jedną - godność. Wszystkie one - jedne trochę mniej inne bardziej - raziły w zestawieniu $\mathrm{z}$ wytworami propagandowej inżynierii realnego socjalizmu, znajdując pewne zrozumienie wśród publiczności. Ale rażą one jeszcze bardziej w zestawieniu z subtelniejszą i skuteczniejszą inżynierią liberalnej mediokracji. Podążanie pod prąd i mało widowiskowa, ale pogłębiona buntowniczość okazuje się cechą konstytutywną tej formy elitaryzmu.

Ale przecież z całym ładunkiem swego anachronizmu i elitaryzmu nie jest Żebrowski zjawiskiem odosobnionym. Stanowi tylko dość skrajny przypadek pomiędzy znaczącymi dokonaniami artystycznymi swojego czasu, poddanymi obecnie procesowi marginalizacji. Wśród uzasadnień, jakie udało się zgromadzić dla lepszego zrozumienia owego anachronizmu, nie ma takiego, które wynikałoby z poczucia pewnego zażenowania, jakie towarzyszy obcowaniu z tworami sztuki, choćby najbardziej szacownymi, lecz pobrzmiewającymi sztucznością, konwencjonalnością. Filmy Żebrowskiego nie mogą zostać potraktowane jako ramota. Ich potencjał sensotwórczy i „wstrząsotwórczy” - żeby usytuować się bli-

[13] B. Zmudziński, op. cit., s. 80-81.

[14] E. Rohmer, Stare i nowe, fragmenty wywiadu udzielonego J.-C. Bietcie, J. Bontempsowi i J.-L. Commollemu, „Film na Świecie” 2002 (nr 403), s. 65. sko sformułowań samego autora - pozostaje nienaruszony, podobnie zresztą jak potencjał wielu innych filmów z tamtej epoki. Których? Każdy wymaga osobnego spojrzenia, żadna wartość nie przenosi się automatycznie.

Wielki i bezkompromisowy konserwatysta, Eric Rohmer, który do końca długiego życia, a więc do stycznia 2010 r., potrafił bronić i rozwijać „niedzisiejszą” formułę swego kina, opartą między innymi na posługiwaniu się kategoriami kultury dawnej, rozciągającej się od antyku po wiek XIX, a używanymi dla opowiadania o współczesności, stwierdził, co następuje: „Otóż jeśli chodzi o mnie, to świat się nie zmienia, a przynajmniej niewiele, nie jest ani bardziej zagmatwany, ani bardziej przejrzysty. Zmienia się tylko podejście sztuki do świata" $[14]$.

Żebrowski problematykę swych filmów umieścił w wysokich rejestrach sfery duchowej życia człowieka, przy czym chodzi tu o bardzo szerokie, nie wyłącznie metafizyczne rozumienie duchowości. Kiedy przygląda się chorobie i umieraniu, to interesuje go nie sam proces psychofizyczny, który rzecz jasna obserwuje, lecz jego skutki dla kondycji bohatera, dla jego reakcji emocjonalnych, postaw intelektualnych i konkretnych decyzji życiowych. A skutków tych nie postrzega bynajmniej w perspektywie takiej czy innej determinacji. Jego bohater w każdym momencie pozostaje istotą wolną, przynajmniej w tym sensie, że zdolną do wewnętrznej przemiany i ostatecznego wyboru. Jest to podejście bardzo odległe od antropologii współczesnego kina, w której jak najgłębsze uzależnienie człowieka od biologicznego, psychicznego, czy też społecznego aspektu jego egzystencji staje się bezwzględnie dominującym sposobem widzenia, w której rozbudowany wizerunek śmierci ogranicza się do śledzenia drastycznych i widowiskowych zarazem obrazów degradującej się materii.

Ale wraz z takim widzeniem sfery humanum, prowadzącym w konsekwencji do zubożenia języka filmowego, wraz z dokonaną wewnątrz filmowej rzeczywistości amputacją 
przestrzeni duchowej wolności owa przestrzeń przecież nie ginie w realnym życiu człowieka. Świat się nie zmienia, a przynajmniej niewiele. A to, co nieprzedstawione, musi prędzej czy później upomnieć się o swoje istnienie. „Na tym polega społeczne znaczenie sztuki: nieustannie wychowuje ona ducha epoki, albowiem wprowadza ona do niej te postaci, których jej najbardziej brakuje. Niezadowolenie każe artyście wycofać się ze współczesności [...]”[15]. Te słowa Karla Gustawa Junga programuja zmiany, jakiś z początku nawet bardzo dyskretny odruch sprzeciwu wobec jednostronności artystycznych kreacji epoki, dyskretny, ale zarazem autentyczny i przekonujący. Utwory Żebrowskiego - oczywiście nie tylko one - bez wątpienia niosą sobą możliwość inspiracji dla takiego sprzeciwu. Mówiąc obrazowo, są rodzajem żaru, który przeniesiony w przyszłość może posłużyć wznieceniu nowych wartości artystycznych w kinie. Niewykluczone więc, iż ich tak dobrze uzasadniona anachroniczność okaże się stanem przejściowym, tylko w pewnym sensie realnym. Dlatego warto je oglądać, warto je pokazywać i warto o nich mówić. Na pewno trzeba też dokonać odkrycia ich samoistnej artystycznej wartości.

Wyraźnie zindywidualizowany język filmowy, jaki stworzył i rozwijał twórca Szansy, nie został ukształtowany w próżni. O inspiracjach nowofalowych, czy o ścisłej współpracy z Krzysztofem Zanussim była już mowa. Warto dodać, że wpływały nań również doświadczenia wyniesione $\mathrm{z}$ amatorskiego ruchu filmowego. Nie był to język raz na zawsze ustanowiony. Zmieniał się i ewoluował od dość radykalnego w swym sfunkcjonalizowanym eksperymentatorstwie Ocalenia po dojrzałą formę $W$ biały dzień. Jego charakterystyka to kwestia bardzo złożona.

Powiada się, że twórczość Edwarda Żebrowskiego to kino intelektualnego dyskursu. Tadeusz Sobolewski ujmuje to dość krańcowo: „Autorytet, jakim się cieszy, nie wynika z czysto filmowych zalet jego warsztatu, ani z ilości błyskotliwych sukcesów. Ten zawodo- wy reżyser pozostaje raczej intelektualistą, który wypowiada się korzystając z kina, niż «człowiekiem kina»." [16] Tymczasem sam zainteresowany postrzega to nieco inaczej:

Przyznam się, że w ogóle nie lubię teoretycznych rozważań, posługuję sie filmem w sposób raczej intuicyjny. Przystępując do realizacji Ocalenia, a jeszcze wcześniej do pisania scenariusza, nie stawiałem sobie żadnej tezy, nie miałem żadnej idei sformułowanej w języku pojęć, którą pragnąłbym zilustrować obrazkami. Po prostu chciałem opowiedzieć pewną historię $[. .].[17]$.

I kontynuuje, przenosząc się ku refleksji bardziej ogólnej:

Oczywiście kino [...] potrafi wyrażać jedynie emocje i stany psychiczne, jest niezdolne do formułowania problemów w ten sposób, jak literatura czy filozofia. Abstrakcyjne pojęcia mogą się stać przedmiotem dzieła filmowego jedynie wtedy, kiedy pokażemy je jako treści emocjonalne człowieka. Nie uważam jednak, żeby to było ograniczeniem; przedmiotem sztuki zawsze jest człowiek i jego przeżycie[18].

Mały ambaras, jaki powstaje z zestawienia tych wypowiedzi, ma swoje podstawy w być może nazbyt radykalnym postawieniu sprawy $\mathrm{w}$ pierwszej z nich. Ale mimo to można sądzić, że da się wyjść z tej sytuacji, respektując oba punkty widzenia.

Sam fakt, iż reżyser odnosi się do kwestii myślenia pojęciowego, nawet jeśli to tylko odpowiedź na postawione przez dziennikarza pytanie, wskazuje, iż coś jest na rzeczy. Emocje jego filmowych bohaterów pochodzą $\mathrm{z}$ ich życiowych doświadczeń, $\mathrm{z}$ tkwiących w nich nieświadomych, wewnętrznych imperatywów moralnych, ale w dużym stopniu także $\mathrm{z}$ obrotów myśli. Wszystkie te postacie prowadzą bogate życie w sferze świadomości, a poprzez zewnętrzne okoliczności zmuszone są nadto do stałego tej sfery pogłębiania i we-

[15] C. G. Jung, Archetypy i symbole, przeł. Jerzy Prokopiuk, Warszawa 1976, s. 377.

[16] T. Sobolewski, „Szpital Przemienienia”,

„Filmowy Serwis Prasowy” 1979, nr 3, s. 3.

[17] E. Żebrowski, op. cit., s. 14.

[18] Ibidem, s. 12. 
ryfikowania. Tym bardziej, że z racji swego społecznego (inteligenci), a także zawodowego (naukowiec, lekarz) usytuowania mogą być do tego specjalnie predestynowane. W efekcie proces myślenia staje się jednym $z$ podstawowych tematów tych filmów. Stwarza to zresztą ewidentnie element ryzyka. Nie jest to jeszcze nic przeciwnego widowiskowej naturze kina, ale trzeba zapytać, czy i ewentualnie w jaki sposób wpływa to na samą istotę filmowego języka?

Odpowiedź na pierwszą część pytania nie nastręcza trudności: bez wątpienia wpływa i to na wielu poziomach. Weźmy dla przykładu kwestię narracji. Prowadzona jest ona tak, że odbiorca staje się obserwatorem procesów rodzenia się nowej świadomości. Śledzi te procesy drobiazgowo, gdyż protagoniści, którzy są ich podmiotami, właściwie nie schodzą z ekranu. Trwa nieustanna, behawiorystyczna wiwisekcja. Taka analityczna perspektywa nie sprzyja zaś prostemu zaangażowaniu emocjonalnemu, utożsamieniu. Trudno być jednocześnie świadkiem i uczestnikiem zdarzeń. Pojawia się więc wrażenie emocjonalnego chłodu, nie tyle wewnątrz filmowego świata, choć i tutaj także, co w relacji utworu $\mathrm{z}$ widzem. A wrażenie to odsyła siłą rzeczy do trochę podejrzanego królestwa rozumu jako ostatniej instancji, ocalającej przed nudą i poczuciem bezwartościowości przekazu.

I rzeczywiście, w mniejszym stopniu w stosunkowo prostej konstrukcji Ocalenia, w większym w wielopłaszczyznowym przesłaniu następnych utworów, interpretacja ich zawartości intelektualnej, opartej w dużym stopniu na formułowaniu pytań, niejednoznacznej i intrygującej, odgrywa bardzo ważną rolę. A jeśli nie interpretacja, to przynajmniej przeczucie doniosłości filmowej refleksji.

Tym owa interpretacja jest ważniejsza, że brak w tych utworach typowego rozwiązania dramaturgicznego, jakim jest bezpośrednie

[19] Nie ma w tych filmach także widowiskowego brutalizmu, charakterystycznego już dla kina lat 70., a naturalnego w obrazowaniu tematów, które porusza Żebrowski. Por. E. Żebrowski, op. cit, s. 19-20. starcie przeciwstawnych racji. Takie starcie oznacza konflikt, a konflikt to przecież życie, to emocje, to wyostrzenie postaw. Zmusza on do wyraźnego wyartykułowania własnego stanowiska lub też własnych wątpliwości. A tymczasem w świecie Żebrowskiego konflikt jest tonowany. Jedna ze stron zwykle milczy, skrywa swoje myśli. Tak czyni lekarz w obliczu wybuchu pretensji docenta Małeckiego. Tak czyni młody psychiatra, gdy swoje poglądy wyłuszcza mu Kauters. Tak samo wreszcie czyni Biały, gdy pierwszy raz rozmawia z Szarym, a także później gdy sucho informuje zwierzchników o przyczynach niewykonania zadania. A zatem to widz skazany zostaje na wykonanie ruchu. Sam musi dopowiedzieć to, co wyrażone zostało tylko po części albo tylko zasugerowane. Aktywność intelektualna wpisana jest więc w ten język niejako kosztem reguł filmowości[19]. To ostatecznie potwierdzałoby słuszność stanowiska Sobolewskiego.

Sprawa jednak nie jest tak oczywista. Wystarczy dokonać prostego zabiegu myślowego, by się o tym przekonać. Jeśli bowiem przychodzi sformułować konkretne pytania, jakie stawiają filmy Żebrowskiego, to okazuje się, że mają one bardzo określony i znaczący charakter. Nie będzie to pytanie w rodzaju: skąd zło? Wypadnie raczej zapytać: czy człowiek może odkryć zło w sobie i jak ma się z niego wyzwolić? Zamiast: dlaczego cierpienie?, zapytamy: jak człowiek może zachować lub zbudować samego siebie w obliczu cierpienia i śmierci? Nie będzie pytania: czy religia może być prawdą?, lecz: czy człowiek bez Boga potrafi pozostać człowiekiem? Pytania, te i inne, rodzą się i nabierają życia tylko w odniesieniu do filmowych bohaterów, którym zdają się one wywracać trzewia. Ani oni, ani ich historie nie są ilustracją, czy egzemplifikacją, lecz źródłem rozważań o wartościach. Dlatego właśnie utwory Żebrowskiego przy całej swej strukturze intelektualnej nie mogą być traktowane jako kryptofilozofia. One tworzą sztukę par excellence.

Dotyczy to również Szpitala Przemienia, adaptacji powieści Stanisława Lema, pełnymi garściami czerpiącej z ducha Mannowskiej 
Czarodziejskiej góry. Ze względu na specyficzne uformowanie anegdoty film ten bywa nazywany traktatem. Oto świeży umysł i wrażliwość adepta psychiatrii konfrontowane są po kolei $\mathrm{z}$ różnymi punktami widzenia, prezentowanymi przez doświadczonych lekarzy, mniej lub bardziej chcących go przeciągnąć na swoją stronę. W rozgrywce nie chodzi wyłącznie o pokusy intelektualne. Kauters, Rygier, Marglewski, czy pisarz Sekułowski to nie woskowe figury reprezentujące swoje światopoglądowe postawy, lecz pełnokrwiści ludzie o wielorakim obliczu. Tutaj w sukurs reżyserowi przyszła nie tylko subtelność własnego scenariusza, ale także wielka sztuka aktorska. To w dużym stopniu dzięki jej wykorzystaniu reżyser potrafił uniknąć ryzyka spłaszczenia przekazu. A że umie się nią posługiwać, udowodnił już przy okazji debiutanckiego Ocalenia, w którym podstawowa i zarazem potężna ekspresja wyrażona została przez gest, mimikę, a nade wszystko spojrzenie aktora odtwarzającego postać docenta Małeckiego, Zbigniewa Zapasiewicza. Tak umiejętne wyzyskanie talentu i warsztatu aktora wiąże się zaś w tym konkretnym wypadku z otwarciem się reżysera na element improwizacji, a więc na kolejne ryzyko.

Filmy Żebrowskiego stoją w poprzek dramaturgicznych prawideł, o czym już była mowa. Nie jest jednak tak, aby mogły one uchodzić za chybione pod względem ekspresji i wywoływały znużenie. Także w odniesieniu do dramaturgii mają one swoją specyfikę. Jeśli autor nie stawia na grę sytuacjami konfliktowymi, to w zamian umie stworzyć narrację zagęszczoną, wydobyć esencję zdarzeń. Jak się okazuje, nawet w tak trudnym przedsięwzięciu, jakim jest Ocalenie, czyli w utworze rozgrywającym się w prologu w murach uczelni, a potem wyłącznie na oddziale szpitalnym, utworze w małym stopniu operującym bezpośrednim znaczeniem słów, których często w ogóle nie ma, można przykuć uwagę odbiorcy właśnie takim rodzajem narracji. Kolejne fragmentarycznie pokazywane epizody wyjęte ze zwykłego biegu czasu, a w wypadku Ocalenia z wszechogarniającej nudy i szpital- nej rutyny, czyli raczej z zawiesiny czasu, okazują się brzemienne w sensy, ale także w napięcie. Nie ma tu pustych miejsc, nie ma oddechu, nie ma zwolnienia uścisku. Można chyba pozwolić sobie na żart i stwierdzić, że to sposób na kino niemal Hitchcockowskie, bo wszak i u polskiego reżysera wszystko zaczyna się od trzęsienia ziemi, choć $\mathrm{w}$ innym wymiarze, a potem ulega tylko wzmocnieniu. $Z$ tego powodu nie mogą to być filmy długie. Możliwości tego rodzaju percepcji, jakiej domaga się Żebrowski, wyczerpują się stosunkowo szybko, nawet w wypadku bardziej widowiskowego $W$ biały dzień.

Kwestia rzeczywistości emocjonalnej, jaka powstaje wewnątrz filmów, ale także na ich styku z odbiorcą, nie da się też łatwo skwitować słowem - chłód. Wbrew pozorom i obiegowym opiniom emocje występują, ba są nawet bardzo silne, choć - tak jak to było w przypadku dramaturgii - sposób ich funkcjonowania odbiega od filmowych standardów. Ów wspominany już tyle razy chłód emocjonalny charakteryzuje nade wszystko relacje międzyludzkie wewnątrz ekranowego świata. Oschłość i milczenie z rzadka tylko przerywane wybuchami uczuć, zawsze zresztą negatywnych, budują ciężką atmosferę alienacji, która nie pozostaje wszakże bez wpływu na widza. Podobnie jak to, co dzieje się za zamkniętymi drzwiami, w odosobnieniu. Właśnie w czterech ścianach swego pokoju płacze rozdarty i bezsilny Stefan; właśnie w obecności sparaliżowanego, niemego, pozbawionego jakiejkolwiek możliwości reakcji ojca Biały pozwala sobie na wyrażenie swego wewnętrznego stanu poprzez na pół dziecięce łkanie. Wielkie znaczenie w tym kontekście mają obecne we wszystkich trzech filmach i we wszystkich bardzo zbliżone w wyrazie sceny erotyczne. Każda z nich pogłębia aurę przygnębienia, gdyż wygląda jak chwilowe, mechaniczne, bezowocne zbliżenie ciał, a w istocie jest beznadziejnym spazmem tęsknoty za drugą osobą, za realnym z nią związkiem. Przy czym owa beznadziejność jest tutaj rozstrzygająca dla emocjonalnego wyrazu, 
także w bardziej rozbudowanym wątku miłosnym Białego i Mecenasowej.

Chłód emocjonalny jest jednym $\mathrm{z}$,bohaterów” kina Żebrowskiego i w ostatecznym rozrachunku przyczynia się on do wywołania owego pożądanego przez twórcę wstrząsu. Pojawia się tu pewne, dość zresztą powierzchowne podobieństwo do praktyki twórczej Roberta Bressona. Z jednaj strony ważkość ekranowych sytuacji i dotykanej problematyki, bliskość bohatera, a z drugiej dyscyplina formalna oraz hamowana ekspresja prowadzą do pobudzenia i jednocześnie utajenia emocji. Dopiero krótki finał dopuszcza do ich uwolnienia. Jednakże przemiana wewnętrznej rzeczywistości protagonisty koryguje owo uwolnienie. Nie jest to emfatyczny wybuch tego, co przez dłuższy czas narastało w ukryciu, ale raczej głębokie, już nie skrywane poruszenie, otwarcie na to, co całkowicie nowe. Taki układ powtarza się w wielu przypadkach u Francuza, a w każdym przypadku u Polaka.

Ostateczny rachunek wyglądałby zatem mniej więcej tak: Edward Żebrowski myśli kinem, tylko myśli niestandardowo i z pewnością nie do końca ściśle. Proces myślenia istnieje u niego in statu nascendi. Refleksja formuje się na naszych oczach i z naszym udziałem. Film nie staje się zakamuflowaną formą intelektualnego dydaktyzmu. Autor Szpitala Przemienienia jest więc przede wszystkim artystą. Owszem, artystą myślicielem (nie mędrcem), artystą moralistą opowiadającym o stanach świadomości swych bohaterów, artystą humanistą, ale bez wątpienia także w pełni artystą filmowym, otwartym na impulsy rozmaitej natury, posługującym się intuicją oraz improwizacją, oryginalnym.

Była już mowa o dyskursie opartym głównie na stawianiu pytań i wyrażaniu wątpliwości. Była próba uchwycenia charakteru tych pytań. Warto jednak odnieść się, rzecz jasna w bardzo ogólny sposób, do samej ich zawartości, a może bardziej do filmowego kontekstu, w jakim są stawiane.

[20] E. Żebrowski, op. cit., s. 16.
Moc, z jaką są stawiane, bierze się ze specyfiki sytuacji, które stają się udziałem bohaterów filmowych. Jeśli nawet jeden $\mathrm{z}$ nich jest w pełnym tego słowa znaczeniu naukowcem, a więc profesjonalnym intelektualistą, to i tak problemy, które go nurtują, które w nim i wokół niego narastają, nie mają nic wspólnego ze studiowaniem najnowszej literatury naukowej przy sterylnym, czytelnianym stoliku, ani też $\mathrm{z}$ analizą wyników laboratoryjnych doświadczeń. Rodzą się dopiero wtedy, gdy to wszystko znika. Nic tu nie jest teoretyczne: ani umieranie, ani zabijanie, ani samotność, ani kwestia wiary. Sytuacje, w jakich znajdują się bohaterowie w każdym wypadku można nazwać doświadczeniem skrajnym. Docent Małecki sam umiera, Stefan sam musi ustosunkować się do faktu eksterminacji pacjentów szpitala psychiatrycznego, w którym pracuje, konspirator i kadrowy bojowiec Biały sam naciska spust, aby wykonać wydany przez partię wyrok śmierci.

Fakt, że cała problematyka etyczno-poznawcza filmów rodzi się z obserwacji doświadczenia konkretnego człowieka, poza tym, że przykuwa uwagę widza, daje filmowi potrzebną dawkę autentyzmu, uwiarygodnia go. Nie można w tym miejscu zapomnieć również o kontekście autobiograficznym, o którym wspomina sam reżyser:

Kiedy kilkanaście lat temu po raz pierwszy przeczytałem Czarodziejska górę, zafrapowała mnie Mannowska koncepcja choroby jako czynnika demonicznego, prowokującego chaos, niszczącego formę. Teza ta długo mnie fascynowała, a jednocześnie podejrzewałem, że w istocie rzecz wygląda inaczej. Osobiste przeżycie pewnych doświadczeń nasunęło mi ostatecznie myśl, że nasze poglądy na sprawy normy i patologii, zdrowia i choroby są chyba zbyt proste. To raczej choroba jest stanem właściwym materii, a zdrowie czymś patologicznym i wyjątkowym. Choroba może być czynnikiem twórczym, porządkującym, nadającym wartość. Zdrowie jest $w$ istocie niepamięcią o tym, że przyszliśmy na świat przypadkowo i bez własnego w tym udziału, zaufaniem krótkiej i nietrwałej chwili. Śmierć tkwi w nas od momentu narodzin, cały dalszy ciąg jest procesem destrukcji, choroby.[20] 
Nie chodzi więc tylko o to, że Żebrowski sam choruje i dlatego lepiej niż kto inny wie, jak o tym mówić. On nie zatrzymuje się przecież na reprodukcji i analizie przeżyć, lecz potrafi wprowadzić je w optykę, która obejmuje odniesienie do kondycji każdego człowieka, także zdrowego. Potrafi odsłonić wewnętrzną pasję poszukiwania jakiegoś rozwiązania, które pozwoliłoby egzystować w bezpośrednim sąsiedztwie śmierci, co jest przecież udziałem wszystkich. Tym różni się ten uwewnętrzniony, płodny autentyzm od wszechogarniającego, upozowanego autentyzmu współczesnych produkcji filmowych i telewizyjnych, owego audiowizualnego przemysłu pod tytułem „historia oparta na faktach”.

Wiarygodność pytań o stan umierania, ich powiązanie $\mathrm{z}$ bardzo konkretną i bacznie obserwowaną tkanką ludzkiego zmagania ze świadomością tego stanu, a także z psychicznymi i fizycznymi jego uwarunkowaniami prowadzi do stworzenia wewnątrz filmowego świata aury perwersyjności. Przede wszystkim w Ocaleniu, ale nie tylko.

Nasza ekranowa współczesność oczywiście bardzo lubi taką aurę. Lubi do tego stopnia, że ją wyraźnie skonwencjonalizowała. Zaś samo słowo perwersyjność urosło zapewne do rangi słowa-fetyszu współczesnej kultury. Bez znaczenia, czy się tę kulturę rozumie jako organiczną jedność, czy też dzieli na wysoką i popularną - fetysz nie traci swego statusu. Decyduje o tym powiązanie tego słowa ze sferą seksualności, w której najogólniej rozumiane jest ono jako odchylenie od normy. Z tej sfery przenosi się ono także na inne, wpisując się w apoteozę najrozmaitszych nisz i meandrów.

Używając go w związku z filmami Żebrowskiego, trzeba jednak pozbyć się owych konotacji, niejako odświeżyć jego rozumienie. Po pierwsze dlatego, że nie zostaje ono wywiedzione ze sfery seksualności, choć do niej także się odnosi, po drugie zaś ze względu na fakt, że nie skutkowało ono szczególną dosadnością przedstawień.

Perwersyjność, jaka pojawia się u autora Szansy, pojmowana być musi szeroko w od- niesieniu do wielu poziomów filmowej narracji, czy też relacji z odbiorcą. Jej znaczenie w tym wypadku polega na pominięciu obowiązujących konwencji (także tematycznych) oraz wywoływaniu reakcji szokowej poprzez ustawiczne wkraczanie w przestrzeń tabu. I nie chodzi tu bynajmniej o kontekst procesu historycznofilmowego, o oryginalność reżysera w stosunku do poprzedników lub współczesnych, o poszerzanie obszaru artystycznej penetracji, o torowanie drogi innym, ale o stwierdzenie wartości bezwzględnej. O tym, że Żebrowski szokuje, będzie można mówić zawsze. A jest to możliwe dzięki skonfrontowaniu bohatera, a w konsekwencji także widza, z sytuacjami w każdym momencie i dla każdego człowieka trudnymi lub nawet niemożliwymi do pojęcia i do przeżycia, skonfrontowanie pozbawione ułatwień związanych z użyciem konwencji albo ilustracyjnością wobec jakiejś koncepcji światopoglądowej.

Umieranie, zabijanie, kuszenie - wszystkie te sytuacje i stany zdają się wręcz domagać obrazów drastycznych, dalekich od tradycyjnych kanonów estetyki, a przy tym obrazów widowiskowych i raczej dynamicznych. Tymczasem Ocalenie to film, w którym znakomita większość dramatu rozgrywa się na twarzy bohatera, w Szpitalu Przemienienia finał tonie we mgle, zaś we $W$ biały dzień zabójca rezygnuje z wykonania wyroku. Nie dzieje się oczywiście tak, aby w utworach tych zupełnie nie pojawiały się sceny drastyczne, ale ostatecznie jest ich niewiele: zasłabnięcie w szpitalnej łazience, sprzątanie łóżka po zmarłym, spazmatyczne zbliżenia erotyczne, zamknięcie na oddziale przewlekle chorych psychicznie, zimny prysznic jako kara, spotkanie twarzą w twarz z człowiekiem, który ma stać się ofiarą. I jeszcze kilka innych. Stanowią one mocne akcenty, ale z pewnością nie dominują. Odkrywany jest raczej wewnętrzny aspekt owej perwersyjności, emocjonalny, intelektualny, etyczny, duchowy. Towarzyszymy bohaterom, którzy bez chwili oddechu poddani są presji niecodziennej sytuacji, którzy zmagają się z narastającymi wewnętrznymi oporami 
i frustracją, z poczuciem udręczenia, z obsesyjnie powracającymi myślami i obrazami.

Owa dyskrecja wiąże się między innymi z zupełnym brakiem fascynacji obrazami śmierci, jaki charakteryzuje utwory Żebrowskiego. Ani śladu piękna rozkładu, czy pornografii przemocy. Namacalne doświadczenie odchodzenia zawsze pozostaje trudne, bolesne i przerażające. Choć stwarza szansę wewnętrznej przemiany, przeczuwane jest jako zło. Świat tych filmów paradoksalnie zintegrowany jest wokół obrazów afirmacji życia jako takiego. I tutaj już pierwszy powód do tak charakterystycznego dla tego kina pesymizmu - bezwzględna konieczność śmierci. Ale nie chodzi tylko o życie jako samowystarczalny fenomen, ale też o życie spełniające standardy esencjonalnych wartości - $\mathrm{w}$ tym jeszcze większy szkopuł.

Laicki obrońca dekalogu - można chyba użyć takiej formuły w stosunku do Edwarda Żebrowskiego jako reżysera filmowego. Dlaczego dekalog - o tym była już mowa. To w nim i wokół niego skupiają się owe esencjonalne wartości. Gdyby przeprowadzić szczegółową analizę, okazałoby się, że wiele filmowych sytuacji (także dialogów) ma bezpośrednie, choć zwykle nie proste odniesienie do konkretnych zapisów: nie zabijaj, nie cudzołóż, nie kradnij... Nie chodzi jednak tylko o to. Rzecz w tym, że wyczuwalna spójność świata wartości, jaki przejawia się w tych utworach, oparta została właśnie na nich. Dramat sumienia, który staje się udziałem głównych bohaterów w Szpitalu Przemienienia i $W$ bialy dzień, rozpoczyna się od nich, a rozwija w oparciu o podstawowe zasady etyki chrześcijańskiej. Tak się bowiem dzieje, że kiedy któryś z polskich reżyserów, zbliżonych pokoleniowo do Żebrowskiego, zabiera się za mówienie o sprawach elementarnych i ostatecznych, chce tego, czy nie, używa języka

[21] Mogłem się o tym przekonać osobiście, przeprowadzając głębszą analizę twórczości K. Kutza i W. Marczewskiego.

[22] E. Żebrowski, op. cit., s. 15.

[23] E. Żebrowski, op. cit., s. 16. chrześcijaństwa. Innym po prostu nie dysponuje[21]. Jak to jest u reżyserów młodszych? Czy mają jakiś inny sposób mówienia, który pozwoliłby im wniknąć na przykład w doświadczenie umierania? Należałoby to zweryfikować. Aczkolwiek rodzi się wątpliwość, czy znalazłby się wystarczająco bogaty i wartościowy materiał analityczny.

Sam autor Ocalenia chce się wyraźnie od chrześcijaństwa zdystansować. Powiada więc:

Obracamy sie wszyscy z konieczności w kręgu interpretacyjnym naszej kultury, nie udaje nam się uciec od jej pojęć, w tym także od terminologii chrześcijańskiej. Tymczasem to, co pani nazywa pokorą, a ja nazywam pogodzeniem, nie musi być przyporządkowane treściom chrześcijaństwa. Jest to podstawowa wartość także w innych systemach światopoglądowych, zwłaszcza wschodnich, np. buddyzmie. Jest ona tam kategorią czysto laicką; podobny charakter miała w filozofii stoików.[22]

Czy mu to wychodzi? A może są to tylko dobre chęci? To kwestia do dyskusji. Niewątpliwie jednak ważna jest tu uwaga o laickim charakterze omawianej kategorii. Przecież o laickości mówi także uogólniająca formula, rozpoczynająca niniejszy fragment tekstu. Skąd to podkreślanie wagi laickości? Wydaje się, że to bardzo konsekwentna deklaracja światopoglądowa autora. Wszyscy główni protagoniści jego filmowych opowieści to ludzie niewierzący. Dwóch z nich fakt ten wyraziście objawia: docent Małecki, kiedy odmawia podzielenia się opłatkiem $\mathrm{z}$ współpacjentami lub w trakcie spotkania $\mathrm{z}$ kapelanem oraz Biały $\mathrm{w}$ rozmowie $\mathrm{z}$ bratem-księdzem.

Podkreślanie przez reżysera laickości nie ma jednak charakteru polemicznego. Nie wynika z jego ideologicznie antyreligijnego nastawienia. Powiada on, że najważniejsze pytanie Ocalenia, a można dodać, że dotyka to wszystkich pozostałych filmów, streszcza się bardzo krotko: Czy człowiek może żyć bez nadziei w sensie metafizycznym?[23]. Oczywiście chodzi tu o życie w najgłębszym tego słowa znaczeniu, o życie z otwartymi oczami, a więc życie w sąsiedztwie zła, cierpienia i śmierci. Nie jest więc także to kino ukrytą 